Sunday, the $27^{\text {th }}$ inst., at the invitation of the Rector (the Rev. the Hon. Canon A. Basil O. Wilberforce), the Members of the Association, accompanied by the Mayor and Corporation, will attend Divine Service at the mother Parish Church of St. Mary, when a sermon will be preached by the Lord Bishop of Truro.

The sectional meetings will be held respectively in some one or other of the following places:-The Watts Memorial Hall, Zion Hall, the Grammar School, Portland Baptist Chapel, Kingsfield School, the Masonic Hall, the Philharmonic Hall, the County Court, the Friends' Meeting House, the Unitarian School, Taunton's Trade School, the Wesleyan School, the East Street Baptist Chapel, St. Andrew's School, \&c.

The Rector has also invited the Members of the Association to a garden party in the charming Deanery Grounds on Monday, August 28, while the Southampton Yacht Club have conferred the privilege of Honorary Membership of their Club for the week on the members, \&c., of the British Association; and the Hartley Council have placed the Hartley Institution entirely at the disposal of such members during their stay. The Dock Company will provide competent guides, \&c., to conduct the members over the splendid series of local docks; and the Union Steam-ship Company will lend and provision their magnificent ship Pretoria for an all-day marine excursion (during which the boat exercise as used in case of storm, and the hose exercise as in case of fire, will be gone through), unless the vessel in question should meanwhile be required by the Government for Transport Service.

The scheme of excursions is very complete, and includes all-day excursions on Thursday, August 3I, to Salisbury, Stonehenge, and Wilton Park; Portsmouth Arsenal, Dockyard, the Royal Yacht, \&c. ; and a marine excursion to Bournemouth, or round the Isle of Wight: as well as afternoon excursions on Saturday, August 26, to Alum Bay; Ryde, Brading, Whitecliff, Newport, and Carisbrooke; drives in the New Forest ; Netley Abbey and Hospital; Romsey, Broadlands (the seat of Lord Mount-Temple), \&c ; Winchester and St. Cross.

The local Gas Company will give an illustration of improved gas-lighting in the Skating Rink, and from Holyrood Church to the Hartley Hall (in one direction), and to the Commercial Road (in the other) ; completely lighting both parts also of Portland Street, \&c. The Edison Electric Light Co. will illuminate the Hartley Hall.

The various local factories (Messrs. Day, Summers, and Co., Northern Iron Works, Oswald, Mordaunt, and Co., Woolston Ship Building Works, \&c.), and the yard of the Royal Mail Steam Ship Company will also be accessible to the Members and Associates with their friends.

The Mayors of Winchester, Ryde, and Newport have shown a hearty desire to co-operate with the Local Executive Committee, as have Lord Mount-Temple, and others too numerous to mention. There appears every probability that, so far as can be attained by sound, honest, local work, the fortheoming meeting will not be the least successful that the Association has held; but it must not be disguised that the Local Committee has been somewhat hampered by the financial difficulty, in which respect there is still time for those who have not sub- scribed to make amends by sending in their names to the Local Treasurer either as Donors, Guarantors, or botb. T. NORFOLK, Assistant Local Secretary

\section{THE CLIMATE OF ALEXANDRIA'}

WTE have before us seven and a half years' very full and satisfactory observations made at Alexandria, under the auspices of the Austrian Meteorological Society, from the commencement of 1875 , from which a tolerably accurate account of the climate of this historically and otherwise important region of the lower Nile may be gathered. The observations have been made daily at 9 a.m., 3 p.m., and 9 p.m., and are quite continuous to the end of May last.

A marked feature of the atmospheric pressure is its comparative steadiness from year to year, attaining the annual maximum, $30^{\circ} 147$ inches, in January, and falling to the minimum, 29.844 inches, in July, the difference being thus 0.303 inch. At Cairo the difference between the winter and summer pressures is 0.321 inch, the greater difference at Cairo being due to its lower summer pressure. The greater diminution of pressure in advancing from the Mediterranean towards the interior during the summer is an important element in the meteorology of Lower Egypt, on account of the changes of wind which result from it.

During the three winter months the direction of the wind in the morning shows a mean of 27 days for S.E., S., and S.W. winds, as against 28 days for N.W., N., and N.E. winds. On the other hand, during the three summer months, southerly winds are wholly absent, and N.W., N., and N.E. winds prevail on 79 days. Looked at broadly, northerly and southerly winds prevail in winter, northerly in summer, and northerly and easterly in spring and during October and November. The prevalence of easterly winds at these seasons is a striking peculiarity of the climatology of a large part of the Levant, and as regards the autumn, they are accompanied with a higher temperature than would otherwise be the case. During the afternoon the wind blows uniformly from some northerly point at all seasons, except in winter, when winds from the west also prevail, west winds being then 16 as against north winds 30 . During the warmest months the wind is wholly from the north. The wind is also much stronger in the afternoon than in the morning. Thus the morning observations give 48 days of calms during the year, but the afternoon observations only I8; and for the seven months from May to November, there are only two days of calm, but for the same months the morning observations give 30 days of calm.

In connection with these changes of wind, the relative humidity is very interesting. The lowest humidity, 66 , occurs in winter; but as the wind changes more completely into the north, the humidity rises gradually to the maximum, 76, in July, and in exact accordance therewith, whilst the daily range of temperature in winter is about I $I^{\circ} \circ$, in summer it is only half that amount. On the other band, while the air at Alexandria approaches nearer

I "Meteorologische Beobachtungen an sechszehn Stationen in Österreich und drei Stationen (Alexandrien, Beirut und Sulina) im Ausland. (Wien, I875-82.) 
towards saturation in summer, the sky at the same time becomes more completely cleared of clouds than in winter. Thus the mean cloudiness in winter indicates that four-tenths of the sky is covered, but in summer there is only one-tenth. This increased relative humidity, occurring simultaneously with increased clearness of sky, is an important feature of the climate of Alexandria, being productive of a heat in the direct rays of the sun much less intense than the clearness of the sky and the latitude might lead us to expect.

The mean annual temperature is $68^{\circ} \%$, the minimum being $57^{\circ} \cdot 6$ in January, and the maximum $78^{\circ} .9$ in August. The coldest January, $54^{\circ} \circ$, occurred in 1880 , and the warmest, $62^{\circ} .1$, in the following year, there being thus $8^{\circ} .1$ of a difference. No such difference occurred in the summer months. Thus the coolest August was $77^{\circ} \cdot 7$ in 1876 , and the hottest, $80^{\circ} \cdot 2$ in 1880 , the difference being only $2^{\circ} .5$. At Cairo the differences of temperature are much greater. The daily range is considerably greater than that of Alexandria ; the mean temperature of January is $54^{\circ} \cdot \mathrm{I}$, and of August $84^{\circ} .5$, and as regards variation of the monthly temperatures from year to year, the mean of January was $50^{\circ} \mathrm{O}$ in 1880 , but $59^{\circ} .2$ in 1881 ; and the mean of August was $80^{\circ} \cdot 6$ in 1876 , but $90^{\circ} .7$ in 1877 , the daily range for the two seasons being thus $9^{\circ} \cdot 2$ and $10^{\circ} \cdot \mathrm{r}$.

At Alexandria the mean annual rainfall is 8.12 inches, falling on 44 days. The largest annual fall was 10.75 inches in 1876 , and the least 3.42 inches in 1879 . The following are the means in inches for the months:January I*95, February I*46, March 0*72, April o`15, May and September $0^{\circ} \mathrm{O} 2$ each, June, July, and August nil, October $0{ }^{\circ} 58$, November ${ }^{\circ} 52$, and December I'70. Heavy rainfalls are of occasional occurrence. During these seven and a balf years the fall for one day exceeded an inch on I 3 occasions. The largest of these falls 3.00 inches, occurred on October 7, 1876. Hail has been recorded on nine separate days in all, and thunder and lightning on eight days.

The following peculiarity in the annual march of the temperature is noteworthy. The mean temperature of June is $75^{\circ} \circ$, July $77^{\circ} 5$, August $78^{\circ} 9$, September $77^{\circ} \cdot 7$, and October $74^{\circ} 4$, from which it is seen that September is warmer than July, and October nearly as warm as June. This peculiarity is still more striking if we look exclusively at the daily maximum temperatures which are so important an element of climate. To show this, we subjoin the means and extremes of the daily maxima, week by week, from July I to October 27 :-

$$
\text { r876-8r. }
$$

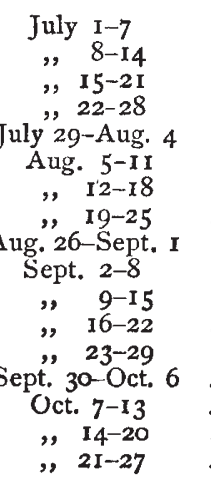

Means.

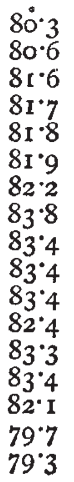

Highest observed.

$86^{\circ} \cdot 2$

$84^{\circ} \mathrm{O}$

$84^{\circ} \cdot 2$

$88 \cdot 0$

$86 \cdot 5$

$86 \cdot 5$

$97^{\circ} 2$

$90^{\circ} \cdot$

$95^{\circ} \mathrm{O}$

93:9

$88^{\circ} \mathrm{O}$

$97^{\circ} 9$

$97^{\circ} 9$

$103 \cdot 1$

$87^{\circ} \cdot 4$

$84^{\circ} \mathrm{O}$
Thus, then, we see that the highest temperatures during the year have taken place in the end of September and the first half of October, and that absolutely the highest temperature yet recorded, $103^{\circ} \mathrm{I}$, was on October $\mathrm{I} 1$, I877; and that while the highest weekly mean occurred in the latter half of August, a secondary maximum, nearly as high, occurred in the beginning of October. It will be also observed that up to the close of October, the temperature is still nearly as high as in the beginning of July, but after this date temperature rapidly declines. That this is no chance result peculiar to the years of observation is shown by the recurrence of this feature of the climate year by year, as well as by the temperature of Jerusalem and other places in the East.

Practically, from May to September inclusive, no rain falls. The precise date of the commencement of rain greatly differs in different years. The following are the dates for each of the seven years, marking the earliest day on which at least one-tenth of an inch of rain fell, which may be considered as marking roughly the termination of the dry season at Alexandria : 0.18 inch on November 4,$1875 ; 3^{\circ} \circ 0$ inches on October 7,$1876 ; 0.22$ inch on October 16, 1877;0.93 inch on November 29, $1878 ; 0.27$ inch on December 20,$1879 ; 0.15$ inch on September 27, 1880; from which date the rainfall was all but nil, till $0^{\prime} 4_{4}$ inch fell on November 27 , and $0^{\circ} 32$ inch on November 15, I881. Leaving out of view the small sporadic fall in September, 1880 , the earliest date for the termination of the summer drought was October 7, and the latest December 20, the mean date of the seven years being November 12 .

On advancing from the Mediterranean sea-board into the interior, the climate rapidly changes; the rainfall becomes less and less, and then practically ceases; the air becomes drier, and the sky clearer; the sun's heat stronger, the nights cooler, and the daily range of temperature greater. At Cairo the rainfall is quite insignificant in amount, but occasionally pretty heavy falls occur. Thus on January 10, 1870, 1.02 inch fell, and on May 3 of the same year 0.67 inch. From January to May of the present year I'I6 inch has fallen, of which 0.80 inch fell during the six hours ending 7 P.M. of April I. The temperature rose at Cairo to $112^{\circ} .6$ on June 5,1872 ; to $\mathrm{II}^{\circ} .2$ on May 25, $\mathrm{I} 873$; and to $\mathrm{II}^{\circ} \cdot 4$ on May $2 \mathrm{O}$, 1869, the highest recorded at Alexandria being as stated above, $103^{\circ}$. I. During September and October, the mean temperature of the two places is nearly the same, with, however, this essential difference, which must not be lost sight of ; the days are much hotter and the nights much colder at Cairo, where consequently greater precaution must be taken against chills at night, these being the fruitful source of diarrhœa, and other complaints which often prove so disastrous during campaigns carried on in such climates as that of Egypt.

\section{COLLIERY VENTILATION}

The Principles of Colliery Ventilation. By Alan Bagot, Assoc.M.Inst.C.E., \&c. (London : Kegan Paul, Trench, and Co., 1882.)

URING the last ten years, or, ever since it has become necessary for colliery managers to obtain certificates of competency by examination, there has been 